\title{
Redbad, the Once and Future King of the Frisians
}

\author{
Han Nijdam and Otto S. Knottnerus
}

Frisian King Redbad (died 719) has become a solid part of Frisian history and Frisian identity in the course of the centuries, and he is remembered as the greatest king the Frisians ever had. It took a very long time for this image to evolve; during and shortly after his life he was portrayed as the prototype of a stubborn pagan king because of his encounters with Christian missionaries and with the Carolingian rulers Pepin of Herstal (died 714) and his son Charles Martel (c. 680-741). It was only through his adoption in the narrative matter of the chansons de geste tradition that the idea of a noble Christian king of Frisia emerged. This positive image would over time come to overshadow the original, negative image. Starting at the end of the Middle Ages, Redbad was portrayed by the Frisians as their king, and he would eventually become the most important king the Frisians ever had.

Our objective is to show that this image of Redbad did not fall out of thin air in the period after 1800 . The manner in which he had been present in chronicles and literature during the entire Middle Ages and the modern period formed the starting point for him to finally to become the most important Frisian king of all times. To our knowledge, this is the first time that Redbad's reception and development is traced in this manner. In this respect, Redbad can be seen as a case study for a more a long-term perspective on the phenomenon of national identities, and as an attempt to widen the scope of this volume. We demonstrate how medieval and early modern developments facilitated Redbad's later reception in the context of modern Frisian identity, which one could interpret as a corrective to exclusively modernistic interpretations of nation-building processes.

We have also taken the liberty to take the concept of mythology to mean the "myth of the nation" because there is a fair amount of myth creation around the Frisian king, both in the chansons de geste and in the Frisian historiography of the modern period, where a continuous line of Frisian kings was forged, working back to Friso, the mythical founder of Frisia.

Despite a considerable dearth of information, both archaeological and historical sources shed some light on early medieval Frisia. Archaeologists now agree

(C) KONINKLIJKE BRILL NV, LEIDEN, 2019 | DOI:10.1163/9789004398436_007 
that the Frisian coasts were largely depopulated between c. AD 300 and 400 and repopulated by people coming from Scandinavia and Saxony from the fifth century onward (Nicolay, 2014). This explains the cultural connections that can be observed between Anglo-Saxon England, Frisia and Scandinavia. Inhabiting the coastal fringes of the continent, the Frisians soon became widely known as traders and as a rich and powerful people. The North Sea was still called Mare Frisicum 'the Frisian Sea' as late as the twelfth century.

Seen in this light, it is not surprising that early medieval sources mention Frisian kings. Legendary Frisian King Finn Folcwalding appears in the AngloSaxon literary texts Widsith and Beowulf (Halbertsma, 2000; Salomon, 2000). During the seventh and eighth centuries, the Frisians clashed with their southern neighbours, the Franks. At the same time, Anglo-Saxon and Frankish missionaries started travelling to the Frisian territories in order to endow the pagan Frisians with the Christian faith. It is through these encounters that one learns of three Frisian rulers - Aldgisl, Redbad, and Bubo or Poppo. Aldgisl resided in Utrecht or Dorestad. He was visited by Wilfrid, bishop of York, in the winter of 678/9. The Frisian king showed great hospitality and even allowed Wilfrid to preach among the Frisians. The next time one hears of a Frisian king, in the year 680, this concerns Redbad. After Redbad's death, in 719, one more Frisian ruler is mentioned. In 734 the Frankish leader Charles Martel defeated dux 'duke' Bubo (of whom close to nothing is known) at the river Bordina (present-day Boorne) in the Frisian heartland; that is, the present-day province of Friesland (Halbertsma, 2000, pp. 229-230, 250-253). It is not known what the relationship was between Aldgisl, Redbad and Bubo. Aldgisl has been seen as Redbad's father or at least his predecessor, but this is not substantiated by the sources (Halbertsma, 2000, p. 77).

This sequence of events shows how the Frisian territory was slowly being conquered by the Franks during the eighth century. The Lex Frisionum (Law of the Frisians) was written down by the end of that century, and it testifies to the fact that the Frisians now fell under Frankish rule. The Lex Frisionum distinguishes three separate regions: one located between the rivers Vlie and Lauwers (i.e., the present-day Dutch province of Friesland), a western realm between the rivers Sincfal and Vlie (i.e., the present-day Dutch provinces of Noord-Holland, Zuid-Holland and Zeeland as well as parts of the province of Utrecht), and an eastern realm between the rivers Lauwers and Weser (i.e., the present-day Dutch province of Groningen, the German district of East Frisia and parts of Oldenburg). This article refers to these regions as Friesland, West Frisia and East Frisia, respectively.

Although Redbad is the Frisian ruler about whom the most has been written in the sources, there are still a number of questions that remain. Redbad's 
name is usually spelled Radbod(us) in the early medieval Latin sources. The earliest attestation of the linguistically Frisian form Redbad can be found in Annales Fuldenses Antiquissimi (Ancient Annals of Fulda, c. 80o; Miedema, 1968). He is alternatively called $d u x$ 'duke, war leader', princeps 'prince, ruler' or rex 'king' in various sources, with the Frankish sources usually calling him $d u x$ and the Anglo-Saxon sources more often calling him rex. Was he the Frisian "super king" as an older generation of scholars likened him to, ruling over all the Frisian regions distinguished in Lex Frisionum? Or was he one of several Frisian rulers, his actual power limited to (parts of) West Frisia (Halbertsma, 2000, 79-92; Egmond, 2005)? It is true that most of the sources with information about Redbad only describe events taking place in this western realm. One episode in The Life of Willibrord, however, is staged on the island of Heligoland (modern-day Helgoland) near the Danish border, and, according to the story, this archipelago was under the rule of Redbad (a closer look is taken at this story below).

Whatever his exact status was, Redbad was a formidable opponent of the Frankish rulers. The battles they fought were hard. Between 688 and 695, Pepin of Herstal (c. 635-714) often had the upper hand and Redbad had to yield Utrecht and Dorestad. During the 69os, a truce was reached. In 711, Redbad married his daughter Theudesinde off to Pepin's son Grimoald (died 714). No children from this marriage are known, although Grimoald's son Theudoald (born c. 708) might well be his and Theudesinde's, based on the evidence of the combination of name elements (Meeder and Goosmann, 2018, pp. 116-122). One of Redbad's sons was probably exchanged as a hostage. According to the Life of St. Wulfram, he was baptised with his father's name, but he died within a few days, still wearing his baptismal clothes (in albis; Levison, 1910, p. 664; Lynch, 1998, p. 129). After Pepin died in 714, Redbad made a comeback. Forming a pact with the Neustrian faction of the Frankish nobility, Redbad reconquered Utrecht and Dorestad and attacked Cologne in 716. Redbad's death in 719 was met with a sigh of relief throughout Frankish Europe (Halbertsma, 2000, p. 93).

Three stories depicting Redbad as a stubborn pagan king were written down in the early Middle Ages and would be retold for centuries to come. The first one stems from The Life of Willibrord, written by Alcuin (735-804) around 795 . Because of his missionary activities in Frisia, the Northumbrian saint Willibrord (c. 658-739) was later called the "Apostle of the Frisians". He was appointed archbishop of the Frisians by Pope Sergius I (650-701) in 696 and became the first bishop of Utrecht.

In chapters nine to eleven of Vita Willibrordi (The Life of Willibrord), Alcuin states that Willibrord travelled from Frisia to Danish King Ongendus (Angantýr according to literary sources), who resided in the coastal town of Ribe. Willibrord 
preached the Christian faith among the Danes with little success. He sailed back to Frisia, taking thirty Danish boys with him, whom he baptised. When they reached an island called Fositesland, after the god Fosite (to whom the entire island had been consecrated), Willibrord ordered his companions to kill and eat the sacred cattle and to draw water from the holy well. The infuriated islanders captured Willibrord and his company and brought them before Redbad. The Frisian king ordered that the lots be cast three times on Willibrord and his followers "according to his custom". Alcuin goes on to inform his readers that God protected Willibrord, and that only one member of the company was appointed by lot to be killed.

This episode in The Life of Willibrord contains some realistic elements. First of all, not all of Willibrord's company were spared. The "lot of the dead" fell upon one of them and he was put to death. Second, a number of sources tell about the practice of lot casting among the Frisians. This adds to the credibility of this account (Pesch, 2003). Third, Saint Liudger, a Frisian missionary that preached among the Frisians living east of the river Lauwers, visited Fositesland again around 790 and Christianised it, destroying the shrine of Fosite and building a church on the island (Diekamp, 1881, p. 26). Finally, Old Icelandic sources (such as Gylfaginning 'The Beguiling of Gylfi' in the Prose Edda) speak of a god Forseti in whom scholars have recognised the Frisian god Fosite (Tveitane, 1995).

The remaining two stories featuring Redbad can be found in Chapters 9 and 10 of the Life of Saint Wulfram, written in the second half of the eighth century by an anonymous writer calling himself Jonas (Levison, 1910). Wulfram (c. 640/50 - c. 700) was bishop of Sens (Normandy) and, like Willibrord, preached the gospel among the Frisians in the last decade of the seventh century.

In the story of the failed baptism (Chapter 9; see Figure 5.1), Wulfram has persuaded Redbad to be baptised. Before undergoing the ritual, Redbad asks Wulfram one final question: will he see his ancestors and the Frisian kings before him again in the Christian afterlife Wulfram promises him after his death? Wulfram answers that, because they died as pagans, they are surely in hell whereas Redbad will reside in heaven once he has been baptised. At this point, Redbad retracts his foot from the font, saying that, if this be the case, he would rather go to hell and see his ancestors again than spend eternity with a bunch of paupers (cum parvo pauperum numero; Levison, 1910, p. 668).

The Life of Saint Wulfram continues to describe the dream Redbad receives the night before he is to undergo baptism by Wulfram. In this dream, the devil appears before Redbad in the form of an angel, adorned with a crown and dressed in beautiful clothes. This figure addresses Redbad as follows: 


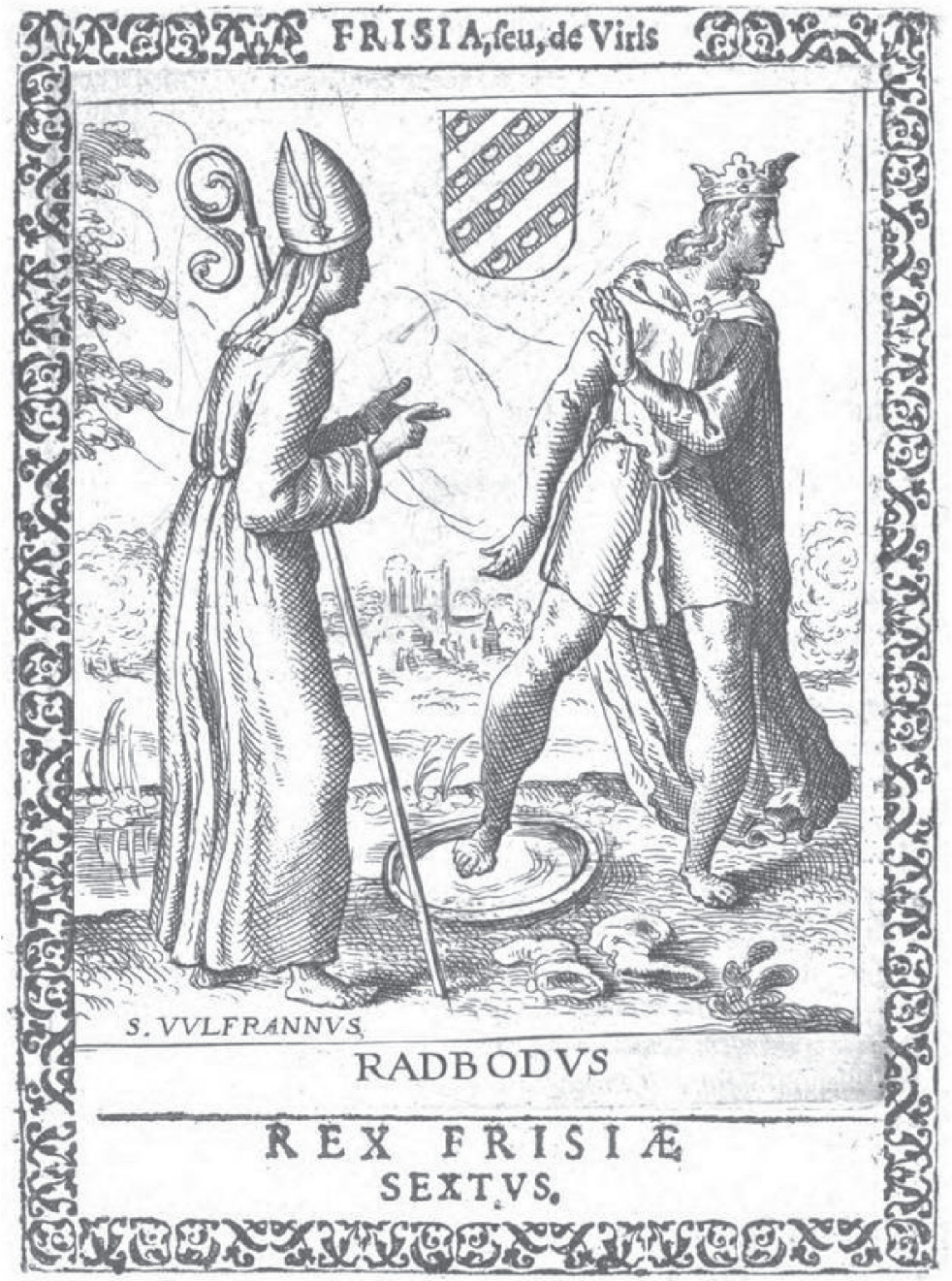

FIGURE 5.1 Redbad refuses to be baptised by Wulfram. Illustration from: M. Hamconius, Frisia seu de viris rebusque Frisiae illustribus (Amsterdam, 1623).

Tell me, I ask you, strongest of men, who has seduced you to consider turning away from the cult and the religion of your ancestors? Don't do it, I beseech you, but stay with the cult of the gods you have adhered to until now, and you will go to the golden abodes which will exist eternally, which I promise to give you, to prove my sincerity.

LEVISON, 1910, p. 669

The next day, Redbad tells Wulfram of his dream. As is to be expected, Wulfram warns Redbad that it was the devil that visited him. To settle the truth of the 
matter, two envoys are then sent from the court of Redbad: one pagan and one Christian. Almost as soon as they are underway, they encounter a third person, who volunteers to show them the golden house that was promised to Redbad in his dream. Indeed, after a long journey through unknown territories, the men come to a wide road, paved with marble, leading to a golden palace;

As they entered the golden and incredibly beautiful house, they saw a throne of immense splendour. Then the guide said: "This is the house and that is the beautiful seat that his god promises to give to King Redbad after his death."

LEVISON, 1910, p. 669

At this point, the Christian envoy makes the sign of the cross saying that if this was made in the name of God it may remain, but that it may disappear if it was made by the devil. At that moment the house and its surroundings vanish, and the two envoys find themselves in the middle of a swamp. They return home, only to find that Redbad has died.

Scholars have debated the meaning, context and background of this story (Eis, 1936; Gosses, 1948; Halbertsma, 2000; Lebecq, 2007; Meens, 2015). Some (Eis, Gosses) argued that the two narratives, that of the dream and the failed baptism of Redbad, belong together and formed one coherent story that circulated among the pagan Frisians in the eighth century. If this hypothesis proves to be correct, one may assume that Redbad was initially remembered by the Frisians as their great king and hero, who had opposed the Franks. In its original form, this coherent story told of the great deeds of a pagan king; how he resisted the new faith and remained loyal to what his ancestors had believed and practised, and how he entered the splendorous Valholl-like halls of his gods (Dillmann, 2007). It is interesting to see that this story fits perfectly into the context of a new religion "testing" an indigenous religion, in this case on the matter of the afterlife. The story also fits the unstable socio-political context of that century; in 784, the Frisians helped the neighbouring Saxons, who openly rebelled against the Carolingian rulers. The Saxons were led by Duke Widukind (743-807), who had returned from his exile in Denmark.

However, the Saxon leader Widukind was defeated in 785 , after which he agreed to be baptised on Christmas Day that same year. In a way, Redbad and Widuking came to be each other's mirror images, Redbad retreating from the font and Widukind stepping into it. Widukind came to be venerated by his aristocratic descendants as a saint (at least since the twelfth century), even though his legacy was also linked to subsequent rebellions against the Frankish king. In a song from the late eleventh century, which only survivesin laterversions, Frisians 
and Flemings support Charlemagne in the final battle against Widukind and his Saxon warriors. As recent studies show, the setting of this story was later relocated to Spain, where the Saxons were replaced by Saracens (Beckmann, 2010, p. 84; Millet, 1999). The original stories about the Saxon war were, however, retold in the Nibelungen tradition, where Widukind is replaced by his pagan successor Liudeger (actually Lothair of Supplinburg, 1075-1137; McConnell et al., 2002, p. 98). This Liudeger, then, reappears in the Frisian tradition as an adversary of Charlemagne, who is subdued by the Frisian standard-bearer Magnus (Buma and Ebel, 1969, pp. 110-119; Mol and Smithuis, 2008, p. 171).

- Reference "Buma and Ebel (1969)" was cited in the text but not provided in the reference list. Please check.

After Redbad's demise, a few centuries passed that hardly left any documentary trace. Between c. 800 and c. 1100, the Frisian lands were part of the Frankish realm. Frisia became a country ruled by Saxon dukes and counts. Most of these officials, however, lived outside of Frisia (Henstra, 2012). Between $85^{\circ}$ and 950, Frisia experienced a Viking Age to the extent that Carolingian rule seriously faltered (De Langen and Mol, 2017). Parts of East and West Frisia were given as fiefs to Danish warlords. During this period and into the 110os, Frisians had contacts of various natures with the Vikings. They traded with them, they were plundered by them and partly ruled by them, and it seems they also went on a few Viking expeditions together (IJssennagger, 2013).

In the aftermath of this Viking Age, the Frisians were able to regain an autonomous status within the empire. This Frisian autonomy, or "Frisian freedom", is discernible from the eleventh century onward (Schmidt, 1963; Vries, 2015). This situation yielded a large corpus of indigenous law texts written in the Old Frisian vernacular. Some of these texts, notably the compensation tariffs, show a clear continuity with the material in the Lex Frisionum, attesting to an unbroken chain of legal practice since the early Middle Ages (Nijdam, 2008). The oldest individual text, Santjin kêsten (the Seventeen Statutes), is traditionally dated to the end of the eleventh century, although the thirteenth-century manuscripts do not offer direct evidence for a written version of these texts predating c. 1200 (Bremmer, 2004). There is however, fragmentary evidence of writing in the Frisian vernacular from shortly after 1100 (Langbroek, 2015).

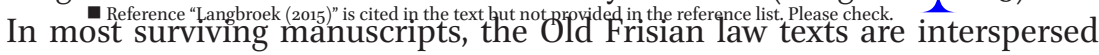
with ideologically motivated narrative comments, which tell how the Frisian freedom was lost in the times of King Redbad and how it was restored by Charlemagne. Moreover, there is a series of chronicles and long poems, dating from the end of the Middle Ages, that tell the story of the Frisian freedom in fourteen 
episodes, partly derived from older Saxon and Frankish sources (Mol and Smithuis, 2008). The first four episodes are relevant to the character of Redbad:

(A) Once there were three brothers called Friso, Saxo and Bruno. They were generals in the army of Alexander the Great.

(B) The three brothers left India and sailed to the shores of the North Sea. There, Friso founded Frisia, Saxo founded Saxony and Bruno became the founding father of Brunswick. Friso had seven sons. Each was granted one of the "Seven Frisian Sea Lands".

(C) The descendants of Friso were subjugated by Redbad, a Danish king. He forced them to wear wooden collars as a token of their enslavement. Saint Willibrord, however, led the Frisians to their freedom by advising them to become lieges to King Charlemagne (c. 747-814).

(D) The two kings, Charles and Redbad, fought over the dominion of Frisia in a duel. ${ }^{1}$ The duel consisted of standing still the longest. At one point, Charles dropped his gauntlet and Redbad gallantly picked it up for him. In this way, the latter lost the duel and left the country.

It is clear that, in these stories, Charlemagne has become the hero of the Frisians because he granted them their freedom. ${ }^{2}$ Redbad is still present at a narrative level, but quite ambiguously. On the one hand, he is made into a villain: a pagan Danish king that subjugated the Frisians. On the other hand, he is a model of chivalry, losing the duel due to civility. The idea of a final duel, moreover, might have been borrowed from the Saxon tradition, according to which Widukind was said to have surrendered to Charlemagne after having lost a duel. It has been recorded in the oldest versions of the Life of Saint Mathilda (written between 974 and 1002) and pops up again in Jehan Bodel's Chanson des Saisnes (late twelfth century) as a reworking of the older traditions mentioned above (Meijering, 1970; Beckmann, 2008, p. 138).

Although these indigenous texts are only known from late medieval sources, the stories they tell probably circulated in the Frisian lands in some form as early as the twelfth century. A singular and mysterious piece of evidence is a spindle weight, dated to the eleventh century, which bears the inscription CERLE REX 'King Charles' (Bremmer, 2004, pp. 24-25). The oldest Old Frisian manuscripts that have survived, dating to the end of the thirteenth century, contain a version of the seventh statute, in which there are clear references to the material about Redbad the Danish king and Charlemagne as the bestower of the Frisian freedom:

1 This "King Charles" must refer to Charlemagne although Charles Martel (c. 689-741), his grandfather, was the actual contemporary of Redbad.

2 This is in line with the great veneration of Charlemagne in the Middle Ages. 
The seventh statute. Our free land, that is, the lawful free chair (within a court of law) where we are allowed to bring a case before court freely and defend ourselves freely. This was given to us by King Charles because we turned away from the Danish king and swore allegiance to the Roman king, so that we paid him taxes and tithes and acknowledged his dominion. Then he led us away from Redbad, the Danish king, and from the tax called clipskelde and from the oaken collars which all Frisians wore around their necks, and from all unlawful dominion. ${ }^{3}$

These stories were widely known among the Frisians throughout the Middle Ages; around 1500, almost every castle contained at least one book with stories on the Frisian freedom (Noomen, 1994, p. 166). In 1525, the nobleman Douwe Gerbranda told the chronicler Petrus van Thabor that the duel between Charles and Redbad had taken place at Kiestersyl, a dike-lock located in the vicinity of the Frisian towns of Harlingen and Franeker (Halbertsma, 1970, p. 89; Noomen, 1994, pp. 167-168).

3

Raimbault, Roi de Frise (c. 100o-150o)

Surprisingly, in spite of his negative reviews, several Frisian noble families claimed to have descended from Redbad. More surprising still, several highranking aristocratic families in Holland, such as the houses of Egmond and Brederode, traced their ancestry back to King Redbad at least since the end of the fifteenth century (Noomen, 1994, p. 167). To understand what was going on, it is necessary to shift the attention from the north to the south.

In the second laisse of the famous Chanson de Roland (Song of Roland), one of the oldest chansons de geste, probably dating from the second half of the eleventh century, a warrior called Rembalt (i.e., Redbad) leads a contingent of Frisian knights to aid Charles Martel in his campaign against the Moors in Spain. It seems, moreover, that he doubles into the champion Rabel, who is entrusted with Roland's sword (in other versions of the story with his horn Olifant). It has been observed that in Chanson de Roland and in other chansons de geste some of the greatest Carolingian adversaries of the eighth and ninth centuries were turned into loyal allies (Beckmann, 2010, pp. 52-54). After his first attested appearance in Chanson de Roland, Rembalt or Raimbault continues to play a role in various chansons de geste, often with his companion and close friend Hamon de Galice, who heads the Flemish contingent.

3 Buma and Ebel (1963, p. 36). On clipskelde, see Nijdam (2009). 
A fifteenth-century poem called Le livre du roy Rambaux de Frise (The Book of King Rambaux of Frisia) has come down in one manuscript. Everything in this story, however, shows that it comes at the end of a long tradition. Here, Rambaux (Redbad) is an old king and the plot actually revolves more around his daughter and her suitor. Barbara Nelson Sargent (1967, p. 27), who studied the sources of this poem for her edition, sums up the character of Rembalt or Raimbault in the corpus of the chansons de geste as follows:

Raimbault was a great warrior and the ruler of Frisia. He fought variously for Charlemagne and against him. He had Doon de Mayence for a father, Hamon de Galice for a companion, Charlemagne's sister for a wife, and Flandrine for a daughter. He died, appropriately enough, in battle, and it was Ogier de Danemarche who struck him down. Of his attributes, three are unvarying: his lordship over Frisia, his prowess in battle, and his connection (in one way or another) with Charlemagne.

This summary shows how much Rembalt/Raimbault/Raimbaut/Rambaux was one of the basic stock of characters in the chansons de geste.

Redbad's fame eventually also reached the far north; he figures prominently in the Old Norse translation of the French material known as Karlamagnús saga (Charlemagne's Saga), dating from the second half of the thirteenth century. Karlamagnús saga is not only of interest because it shows how widely this literature spread, but also because this work contains some material that has not survived in its regions of origin. On the basis of this evidence, the philologist Paul Aebischer convincingly argued that there must have existed a Geste de Raimbault et Hamon (The Deeds of Raimbault and Hamon), which he dated to the late eleventh century. In the restyling of the story around 1200, commissioned by the bishop of Liège, Redbad became a predecessor of the counts of Holland (and thus serving their political aspirations), ruling the entire coastal area between Flanders and Denmark on behalf of the emperor. According to Karlamagnús saga, Charlemagne bestows on him three lances with white gonfalons, which apparently refer to the triple bends in his coat of arms (see below; Aebischer, 1957, p. 24; Beckmann, 2005, p. 390).

Once the concept of a Frisian king had been infused into the corpus of the chansons de geste, literary fiction took off and created some extravagant by-products. Already in Historia Karoli Magni et Rotholandi (History of Charlemagne and Roland), a crusade manifesto from the 1130s by an author known as the Pseudo-Turpin, Frisian King Gandelbodus is mentioned as one of the heroes that died in the Battle of Roncevalles. His remains may apparently be visited along the western pilgrim route to Compostela in the Gascon village of Belin, resting in a collective tomb with his fellow warriors Olivier, Ogier (Holger) 
the Dane and other heroes. According to a contemporary travel guide, the sweet fragrance emanating from it can heal the sick (Pita, 1882, p. 44).

Although it is difficult to reconstruct where the story originated, it might be conceivable that the name Radbodus was somehow misinterpreted or misread as Gandelbodus, and confused with another character, Gundobad of Burgundy (c. AD 452-516). The name is then garbled into forms such as Gondebald,

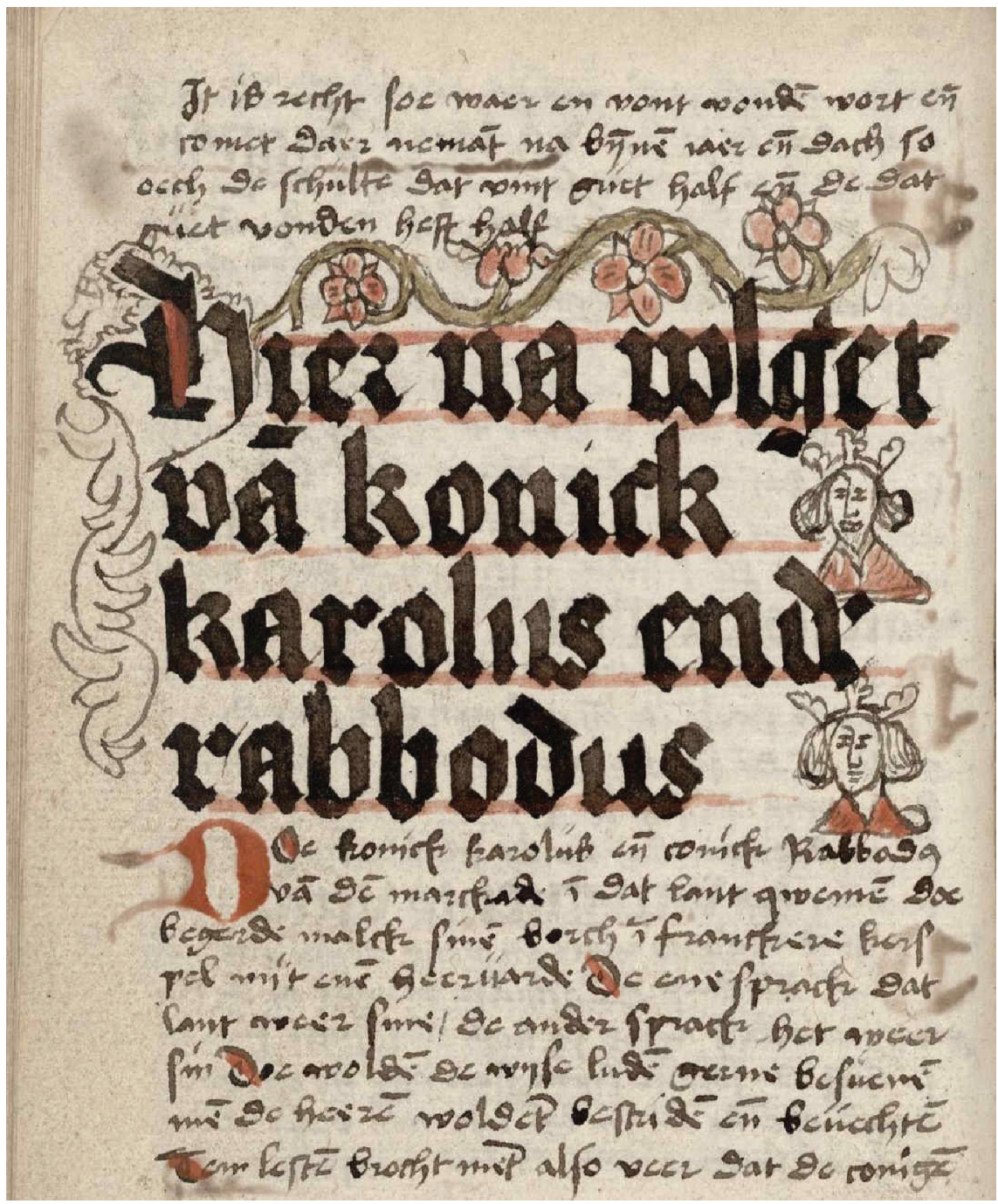

FIGURE 5.2 Opening page of the text The Tale of Kings Charles and Redbad. Page from a Low German manuscript from the sixteenth century SOURCE: TRESOAR LEEUWARDEN, VON RICHTHOFEN COLLECTION, MS. R7 
Gondelbuef, Gondrebrues, Gouldebeuf, Gandobol and Gundilber (Jongkees, 1961; Moisan, 1986, pp. 240-241). This Gondebald is a prominent character of the chansons de geste, a close friend of Roland. An Occitan catalogue from the 1170 mentions the chanson of Gondalbon lo Frizon, together with Rambaut et N'Aimon and an unknown song about a certain Frizon. The latter might be the warrior Saint Fris, who apparently fell in the village of Bassoues near Auch in 732. At the close of the Middle Ages, this Saint Fris came to be known as the son of the king of Frisia, who wore the famous war banner of France. Seventeenthcentury clerics then eagerly identified him as Redbad's baptised namesake mentioned in Vita Wulframni (The Life of Wulfram; Pirot, 1972, pp. 548, 551, 553; Bénac, 1916-1923, pp. 67-102).

To sum up, at least three Redbad characters are encountered between c. 1000 and c. 1500 . First, the reports on the historical Redbad in the Frankish annals and chronicles continued to be copied and used in later accounts. Furthermore, the lives of Wulfram and Willibrord remained in circulation, which meant that the stories of Redbad's failed baptism and of the episode at Fositesland were available throughout this period. Second, within the Frisian borders a new Redbad arose. Because the Frisians attributed their freedom to Charlemagne, they could not depict Redbad as a hero. Instead, his character took on the image of a Danish pagan king, subduing the Frisians and forcing them to wear a wooden collar as a token of their serfdom. Nevertheless, in the story of the duel between King Charles and King Redbad, the latter acts valiantly, picking up the gauntlet Charles dropped as a ruse to win the duel. Future research might reveal a link between this story and the third form, in which Redbad appears: that of Frisian King Raimbault in the chansons de geste. The character of the chivalric Raimbault developed into that of a righteous Christian knightly king. He was even "cloned" a few times, leading to several Frisian kings, of which Gondebald or Gondebeuf was the most widespread.

The multiple Frisian kings in the chansons de geste gave birth to the notion that there existed a Frisian Christian kingdom. In the minds of the French-speaking audience of the chansons de geste, this realm was situated somewhere far away in the north. At some point, medieval heralds came up with a coat of arms of the Frisian kings, which is first attested in French and British armorials toward the end of the thirteenth century (Adam-Even, 1954). Modern heraldic scholars are convinced, however, that its origins lie further north, probably in the Frisian regions (Brault, 1993, pp. 32-34; Goodall and Brault, 1994, pp. 295-297). 


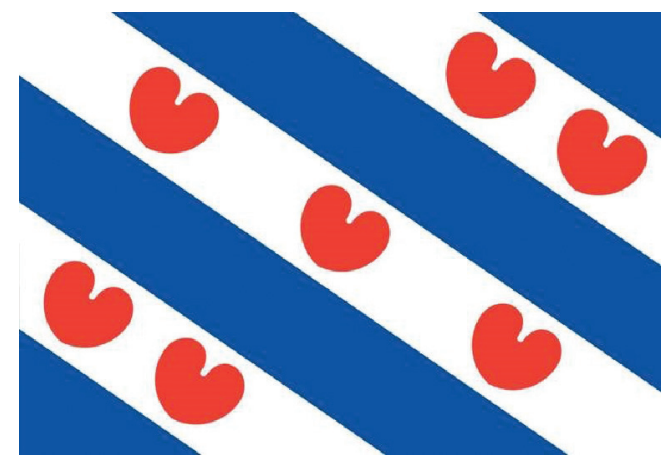

FIGURE 5.3

The official flag of the Dutch province of Friesland SOURCE: WWW.ECHTEFRIESEVLAG. NL

It consists of three white (silver) bends on a blue field, the bends adorned with red hearts, which are commonly interpreted as stylised leaves of the water lily (Nymphaea alba). In heraldry, these are known as sea-leaves (Frisian: pompeblêden). The colour red was introduced in the late fourteenth century, probably in order to underline the royal status of the design; older specimens bore a semy of white leaves. The number of hearts or leaves varied over time, but is now fixed at seven, symbolising the Seven Frisian Sealands mentioned earlier (see Figure 5·3).

Since the last decades of the fourteenth century, one finds attestations of the continued use of this coat of arms in the Dutch province of Friesland, the heartland of modern Frisia, as well as in West Frisia. ${ }^{4}$ The original design is included in the coat of arms of the province of North Holland, approved in 1907. It consists of two golden lions passant (and "guardant"; that is, looking at the viewer) on a blue field interspersed with silver pennies. In an early fifteenth-century Hollantsche Cronike (Holland Chronicle) by the herald Claes Heynensz, this coat of arms is explicitly called that of "Rabboldus", king of the "Vriensen" (i.e., Frisians; Vries, 1995, p. 94). It was introduced in Friesland after the end of the Frisian freedom in 1498, whereby the pennies were replaced by golden bricks. The number of bricks became fixed at seven, again as a reference to the Seven Frisian Sealands. Sixteenth-century heraldry books sometimes depict both coats of arms, either with bands or lions - the former referring to the ancient kingdom of Frisia, and the latter to the actual lordships of West Frisia and Friesland.

For both coats of arms, there is an inherent connection to Scandinavian heraldry. Various coats of arms of medieval Scandinavian kings show red waterlily

4 The first erroneous records of the coat of arms of the "rey de Frisia", here still confused with Denmark, stem from Catalan sources (Ricquer, 1987, p. 316). 
leaves, lions, blue background colours and sometimes - as in the Swedish case white bends comparable to those in the Frisian flag. According to Olaus Magnus (1555), these bends were perceived as "white streams on a field of heavenly blue", apparently representing the waterways subdividing the country (Olaus Magnus, 1555, p. 88). The novel colour blue, moreover, was highly valued as an alternative to the aristocratic red (Pastoureau, 2001). The High German Kudrunlied from the 1230 is the first to describe a banner of sky-blue silk studded with sea-leaves, attributed to the fictitious model King Herwic of Sêlande. The Frisians are amply documented in this poem, which is set somewhere in the coastal area between Flanders and Denmark and must have had older predecessors. ${ }^{5}$ Perhaps the sea-leaves were perceived as a token of freedom and personal honour. According to a fifteenth-century tradition, the red leaves in the coat of arms of Engern - Widukind's home-country - were given to the Saxons by Charlemagne himself (Bote, 1868, p. 485). The Frisian tradition, however, maintained that the emperor granted them a royal crown to be depicted on their shields as a token of their privileged status.

Because the notion that Redbad was a Danish king seems to have existed early on, these Scandinavian parallels to the coat of arms are not surprising. Indeed, in his memoires, written around 1528 while imprisoned due to the political upheavals of his time, the Frisian nobleman Jancko Douwama (1482-1533) tells an appealing story (Amersfoordt et al., 1849, p. 39); around the time of Frankish King Pepin, the Danish king conquered many lands, including England and Frisia. He gave the latter to his beloved youngest son, Radboet (Redbad), and took two lions from the Danish coat of arms, which consisted of five until that time, and gave them to Redbad. Redbad put these lions onto the old Frisian coat of arms, which consisted of seven golden spanen 'boards, bricks, billets' on a blue field, thus creating the Frisian coat of arms as it is still known today (see Figure 5.4). ${ }^{6}$

This story may well have been borrowed from a Low German tradition stating that the pair of Brunswick lions had been granted around 1170 to Duke Henry the Lion by his father-in-law King Henry II of England, who kept three lions in his coat of arms (Meibom, 1688, p. 54). ${ }^{7}$ Nonetheless, the story might hint at the fact that the lions were a secondary addition to the original coat of arms, only consisting of bends and sea-leaves. Additionally, both were associated with Redbad.

5 The antiquity of the Kudrunlied is probably overstated by Voorwinden (2003).

6 Except that both the Frisian and the Danish coats of arms used to have lions passant guardant, which were called leopards as heraldic figures, and that both now feature lions passant; that is, looking straight ahead.

7 The same holds for the Duchy of Schleswig. 


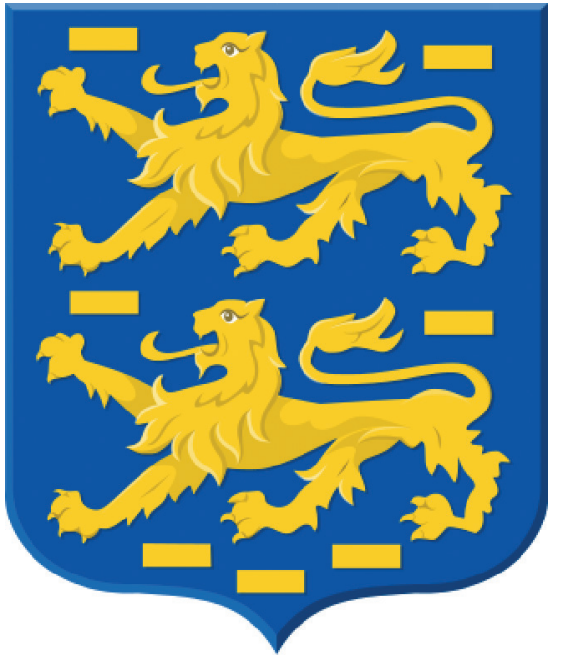

FIGURE 5.4

The official coat of arms of the Dutch province of Friesland SOURCE: WIKIMEDIA COMMONS

Politics often played a major role in the way Frisia and a Frisian kingdom were portrayed in terms of heraldry; Philip the Good (1396-1467), Duke of Burgundy, was very much aware of the fact that as hereditary count of Holland, Zealand and West Frisia he could also lay claim to Friesland east of the Vlie River. Holland, moreover, had been founded from a former part of Frisia. If Frisia had been a kingdom once, this meant he could also claim the title of king. Consequently, heraldry provided extra ammunition for the political struggle the Burgundians were fighting against the kings of France (Sargent, 1963, p. 28; Jongkees, 1946; Verbij-Schillings, 1997).

In 1956, when the province of Friesland wished to have its flag officially documented and registered, the Frisian Academy (Fryske Akademy) commissioned a group of historians to study its historical roots. The commission reported on its findings in a special issue of the journal of the Frisian Academy, It Beaken, in 1956 (Bruch et al., 1956; Vries, 1995). This was the first time the connection between the Frisian flag - that is, the old coat of arms of the king of Frisia - and Redbad was made explicit. It facilitated a stronger emphasis on Redbad as the most important king of the Frisians.

In the case of Friesland, the Middle Ages ended quite abruptly in 1498. After long and fierce internal struggles, Emperor Maximilian bestowed the title of hereditary governor of Friesland upon Albrecht, Duke of Saxony (1443-1500). As a result, an effective central government was formed in Frisia for the first 
time since Charlemagne, and the Frisian freedom that had lasted for centuries came to an end (Vries, 2015). One of the far-reaching changes was the abandonment of Old Frisian traditional law in favour of Roman law.

This new situation affected chroniclers, who now began to ask themselves what had gone wrong. Why had the Frisians lost their precious liberty? As a result of the Dutch Revolt in the sixteenth century, however, things changed for the better again; in 1578, Friesland became one of the provinces of the newly established Dutch Republic, and thus regained its autonomy. After this period, a new historiography can be observed. Apart from the fact that the impact of the Renaissance or Humanism can be felt in these works, a strong accent was now placed on the role of the Frisian nobility in Frisian history. This led to an impressive but largely imaginary genealogy of Frisian kings, reaching back many centuries (Noomen, 1994).

Two chroniclers from the beginning of the sixteenth century need to be addressed. The first of these, Jancko Douwama, has already been mentioned. Together with the fifteenth-century Frisian chronicles mentioned earlier, Douwama's text provides evidence that the chivalric tradition (i.e., the chansons de geste tradition) concerning Redbad was known in Frisia around this time. Douwama explicitly mentions some details about Redbad's life and his descendants that are, without a doubt, derived from chivalric literature, such as the name of Gondebald (Gandelbodus), who is made into one of three sons that Redbad apparently had. Douwama knows that Gondebald was killed at Roncevalle, together with Roland, which points to the writings of PseudoTurpin. Douwama also states that one of the descendants of Redbad was Prester John, the legendary Christian king of India (Amersfoordt et al., 1849, pp. 46-47).

Thabor was an Augustinian monastery near the town of Sneek in southwestern Friesland, founded at the beginning of the fifteenth century. Between 1517 and 1538, Worp of Thabor, a regular canon of the monastery, wrote a chronicle divided into five "books" or parts. It treats Frisian history from its earliest beginnings up to the age of the author. Worp is very explicit about the sources he uses for his work and thus offers valuable insight into the library of one of the Frisian monasteries, which were mostly destroyed after the Reformation in Frisia (1580). Worp uses Classical authors such as Tacitus and Caesar, who reported on the Germanic peoples. He explicitly refers to Vita Wulframni to tell the story about Redbad's failed baptism and his dream (Ottema, 1847, pp. 54-56). Worp also has knowledge of a King Gondebald that died at Roncevalles. Apparently, he was the brother of King Redbad "of whom the lords of Egmond are said to have descended” (Ottema, 1847, p. 91). So here again one can see where this information came from; Worp had read a chronicle 
from Holland that traced the ancestry of the noble family of Egmond back to Redbad, probably the influential Division Chronicle by Cornelius Aurelius, printed in 1517 (Bolhuis van Zeeburg, 1873, p. 98).

In 1873 , the study on Frisian historiography by Jan Bolhuis van Zeeburgh marked the end of a long period in which many Frisians still more or less held the legendary Frisian chronicles to be true, despite the devastating reviews by more critical historians such as Ubbo Emmius (1547-1625). In this tradition, the work by the mysterious author Andreas Cornelius played a key role. It was written around 1578 and printed in 1597, and, somehow, it was able to propel medieval material into the modern age, sketching a fabulous - or, rather, fabulated - image of ancient Frisian history that proved so appealing to the Frisians that they clung to it for centuries to come (Jensma, 2004, pp. 74-86). The text is unique in many ways. It pretends to be the work of four consecutive authors: Solcko Forteman (c. 76o), Ocko Scharlensis (c. 96o), Johannes Vlietarp (c. 1312) and finally Andreas Cornelius himself (c. 1560). Bolhuis van Zeeburgh showed that the first three of these authors must have been invented by the actual author of the text in order to authenticate his information. It is not even known whether Andreas Cornelius was a real person; Edzo Waterbolk (1995) suspects this was a nom de plume for the politician Joachim Hopperus (15231576), on whom more below.

In a way, Frisian historiography was standing at a crossroads in the sixteenth century. Bolhuis van Zeeburgh is very explicit about his own preferences. He praises Worp of Thabor for his diligent use of the sources available to him and chastises Andreas Cornelius for fabricating the ancient history of the Frisians. His lamentation at the end of his paragraph on Worp cannot be misunderstood: "If only later historiographers had followed in Worp's footsteps! But Andreas Cornelius' book spoiled everything” (Bolhuis van Zeeburgh, 1873, p. 109).

Although the damage done by Cornelius was bad enough, its negative impact was increased by the works of the first official "state historian" (landshistorieschrijver) of Friesland, Suffridus Petrus (1527-1597). Suffridus Petrus had studied Latin and Greek at the University of Louvain and taught at the universities of Louvain, Erfurt and Cologne. Between his appointment in 1590 and his death in 1597, he was able to finish only two of the sixty books on Frisian history he had planned: De Frisiorum antiquitate et origine (1590) and De scriptoribus Frisiae (1593; Bergsma, 1994; Noomen, 1994).

Suffridus Petrus tried to forge all sources at his disposal into one sweeping narrative: the "big history" of the Frisians, so to speak. Unfortunately-according to Bolhuis van Zeeburgh - he made ample use of the material presented to him by Andreas Cornelius. This enabled him to create an unbroken line from Friso, the mythical founding father of the Frisians, to the present day of 
Suffridus Petrus' own age. It resulted in the following list of consecutive "princes", “dukes", "kings", "potestates" and "archgovernors":

7 Principes (Friso conditor Frisiae, Adel, Ubbo, Asinga Ascon, Diocarus Segon, Dibbaldus Segon, Tabbo)

7 Duces (Asconius, Adelboldus, Titus Boiocalus, Ubbo, Haron Ubbo, Odilbaldus, Udolphus Haron)

9 Reges (Richoldus Uffo, Odilbaldus, Richoldus II, Beroaldus, Adgillus, Radbodus, Adgillus II, Gondobaldus, Radbodus II)

Carolus Magnus, libertatis et insignium modernorum Frisiae dator 16 Potestates (Magnus Fortema, Taco Ludigmannus, Adelbricus Adelen, Hesselus Hermana, Igo Galema, Gosso Ludigmannus, Saco Reinalda, Regnerus Cammenga, I.H. Martena, Ivo Juwinga, Galo Hania, Sixtus Dekema, Odo Botnia, Suffridus Wiarda, Haringus Harinxma, Julius Dekema)

5 Archigubernatores (Albertus Dux Saxoniae, Georgius Dux Saxoniae, Carolus v Caesar, Philippus Rex Hispaniae, Albertus et Isabella archiduces Burgundiae, etc.)

As can be observed from this list, by this time several characters had been split into two kings with identical names. This had also happened to the most important historical characters before Charlemagne: Aldgisl and Redbad.

Notwithstanding this overwhelming number of Frisian kings and princes, Redbad retained his special position. One of the pieces of evidence for this is a portrait tradition depicting Redbad that started after the middle of the sixteenth century. One first learns of this tradition from the correspondence between Joachim Hopperus (1523-1576) and Viglius Aytta (1507-1577), two highly influential Frisian politicians serving the central government. Hopperus collected a huge collection of Frisian antiquities - manuscripts, maps and objects. In several letters dating between 1570 and 1571, Hopperus asks his friend to send him the portrait of Redbad owned by Aytta so that he can have a copy made of it (Wild and Altheer, 1802, pp. 283, 312, 328). Attestations of such portraits of Redbad can be found in West Frisia, Friesland and East Frisia from the end of the sixteenth century onward. Quite a number of copies must have circulated, although today only two exist. One hangs in the city hall of Medemblik, where the West Frisian tradition concerning Redbad has retained a firm basis. A castle built by the counts of Holland in the early fourteenth century came to be known as Radboud Castle in the nineteenth century. The second copy resides in Leeuwarden and is the property of the Royal Frisian Society for History and Antiquity (Koninklijk Fries Genootschap voor Geschiedenis en Oudheidkunde).

It can be concluded then that during the period between c. 1500 and c. 1800 the story of the ancient Frisian history was made complete. The blanks of 
many ages were filled in with rows of fabled kings that had been figments of the imagination of various chroniclers of past centuries. They were compiled and ordered into a neat story by Suffridus Petrus. Among all these Frisian kings, Redbad still retained a special place.

At the beginning of the nineteenth century, the perception of Frisian history and identity were greatly affected by two major developments. After the defeat of Napoleon Bonaparte in 1813, the Kingdom of the Netherlands was formed. This transformed Friesland from an independent federal state within the Dutch Republic into a province of a centralised kingdom ruled from The Hague, two hundred kilometres to the south. During the heyday of the Republic, Friesland had been the second-wealthiest province after Holland. Now, its economy became increasingly marginalised, so that around 1900 the common perception prevailed that Friesland was a slightly backward and largely rural area. Napoleon had already closed down the University of Franeker in 1811; founded in 1585, it had been the second-oldest in the Netherlands, after Leiden. The university was replaced by an Athenaeum, which subsequently closed its doors in 1843 (Jensma, 2012). From then onward, the province lacked a centre of higher education. The shrinking nobility followed the trend and largely left the province; only a few aristocratic families remained.

In the early days of the new kingdom, several issues had to be settled. One of these was the unification of the regional elites into a single nobility under the direction of the new king, Willem I. More than once Frisian noblemen refused the novel titles of count or baron. They preferred the indigenous title of jonker, but in the new system this meant that they were only entitled to the rank of jonkheer, which denotes the lower nobility or landed gentry. Some of them pleaded that they deserved better treatment because they descended from Frisian King Redbad (Noomen, 1994; Dijkstra, 1895-1896, p. 110).

The early 1800 s also saw the rise of the Romantic movement, and a renewed interest in traditional culture also affected the Frisian language. The educated elite started writing and reading in Frisian, which had only been in use as a spoken language for centuries. The Frisians had their own Grimm brothers: Justus, Eeltsje and Tsjalling Halbertsma, of whom the first was the most prolific. Justus Halbertsma (1789-1869) corresponded intensively with various scholars throughout Europe, including Jacob Grimm (De Jong, 2009).

In 1825, the Halbertsma brothers wrote a collection of short stories in Frisian. This publication may be seen as the beginning of Modern Frisian, marking the point where Frisian once again became a written language. The little 
volume eventually grew into an extensive collection of short stories and anecdotes: Rimen en Teltsjes (Rhymes and Stories). In 1829, Justus Halbertsma wrote a fairy tale about an old soldier that is forced to become a physician and heals a princess. The story is called "Miswier" (Continuously Bad Weather) and is set at the court of King Redbad, who is depicted as a model king typical of fairy tales (Breuker, 1993, pp. 68-76). Redbad is called "Radbod the Second", and so Halbertsma's inspiration clearly came from the tradition of Andreas Cornelius / Suffridus Petrus.

Like the Grimm brothers, the Halbertsmas collected fairy tales and other folklore material, but not as systematically as their German counterparts, and they did not publish the result. Others did, however, and so one can now study the folk traditions concerning Redbad from West Frisia, Friesland and East Frisia (Wiersma, 1934, 1937, 1973). As with all folktale studies, it is sometimes difficult to distinguish oral traditions from material recently derived from written sources. As can be expected, the influence of material from Vita Wulframni and Vita Willibrordi is detectable. West Frisia has yielded more than fifteen stories in which Redbad is the main character. Some depict him as a stubborn pagan king, but most of them as a noble Frisian king that defends his people. In one of them, he receives a magical sword called Asbran from a magical ancient warrior that comes to him in the form of a black swan accompanied by six white swans that transform themselves into beautiful women.

The legal historian Arian de Goede (1915-1957) from de Purmer played a prominent role in the creation of a more ideological image of Redbad. Together with his father, he founded the West-Frieze-Styk (West Frisian Association) in 1932, a society for the conservation of culture, language and folklore devoted to the study of the history of West Frisia. De Goede wrote a volume on the historical Redbad (1946), in which he emphasised the historical continuity between pagan Frisia and (early) modern Dutch history; he maintains, for instance, that it is no coincidence that it was the descendants of these noble heathens that, during the sixteenth-century Reformation, smashed "Christian statues” wherever they saw them (De Goede, 2018, pp. 40-41). Thus, Redbad and the indigenous pagan culture he represents could be perceived as Protestant avant la lettre. In De Goede's personal archive, now in the Frisian Academy, there used to reside an unpublished typescript of 158 pages titled "Heroic Tales of King Redbad of Frisia according to the West Frisian Tradition", dated 1956 (Arends, 2002, p. 12). This typescript was unfortunately borrowed out in 2002 and never returned.

There is also supposed physical evidence of Redbad in West Frisia. Mention was already made of Radboud Castle at Medemblik. The church at Hoogwoud houses a stone font from the end of the thirteenth century, which is said to 
have been the font Redbad was almost baptised in (Halbertsma, 2000, p. 244). Furthermore, a "Redbad Road" and a "Redbad's cemetery" can be found in the area (Halbertsma, 2000, p. 248).

The province of Friesland, the old Frisian heartland, has yielded a meagre harvest of folktales concerning Redbad (Wiersma, 1973; Halbertsma, 1970). Only a few "baroque" tales have been written down in which Redbad is a typical fairy-tale king or in which only elements of the baptism story, the dream or the Fositesland episode are used. The physical memories of Redbad are scant as well; there is one attestation of a "Redbad Road" and one source from 1754 mentions a plot of land called Radbodus Hemelrijk (Redbad's Heavenly Kingdom), undoubtedly a reference to the story of Redbad's dream (Halbertsma, 2000, p. 248).

In Groningen and especially East Frisia, a very different picture emerges (Sello, 1921/1922; Wiersma, 1973; Halbertsma, 1970; Halbertsma, 2000). Not only are there several Konrebberswegen (King Redbad Roads) attested in this region since the fifteenth century, but Redbad is also said to have travelled these roads. Moreover, he also travels the skies because he becomes the leader of the Wild Hunt (Lübbing, 1928, pp. 214-215; Wiersma, 1934, pp. 260-261; Wiersma, 1937, pp. 36-37). Other famous leaders of this army of the dead are the Germanic god Wodan and a handful of very famous medieval kings, such as Charlemagne and Emperor Frederick Barbarossa. At Berumerfehn, there is a Radbodsgehölz 'Redbad's Woods', which contains a monument made of four megaliths, one of which bears the inscription Radbod Rex Frisiae. Ao Dcc VIII 'Redbad king of Frisia. Anno 708'. There are also a few hills called Konrebbersberg (King Redbad's Mount), where Redbad is supposedly buried (Sundermann, 1922, pp. 20-26). The old king is not dead, however: he is asleep and will awaken again when his people need him the most. In this setting, Redbad truly develops the characteristics of a Rex iustus rediturus, a just king that will return in times of need. Thus, Redbad becomes a member of an elite group of kings of whom the same is said: Arthur, Charlemagne, Holger the Dane and Frederick Barbarossa, to name the most famous examples (Samplonius, 1993).

Although Central Friesland did not have a strong folklore tradition concerning Redbad, the region caught up later; in the course of the nineteenth century, Redbad became increasingly important as a symbol of Frisian nationalism and Frisian identity. Two songs were composed for him in the influential Frysk Lieteboek (Frisian Songbook), which was published in 1877 (Faber, 2003, pp. 232-237). As the Frisian (Emancipatory) Movement started to grow over the course of the twentieth century, striving toward greater independence for the Frisian people and an official status for the Frisian language, more poems and plays were devoted to him. The fact that Frisia had once been a kingdom 
with a famous king was an element that could be, and at times was, used in their political struggle.

Miedema (1968, pp. 52-53) pointed out that the book Bodders in the Fryske Striid (Protagonists of the Frisian Cause) by Geert Aeilco Wumkes (1869-1954), which was published in 1926, marked a turning point. Wumkes drew attention to Redbad's name and the fact that the correct Frisian form of it was Redbad, and not Radbod or Radboud. As soon as the Frisian students at the University of Utrecht realised the mistake they had originally made by calling their association Radbod at its founding in 1930, they changed it to Redbad a few years later.

The writer Douwe Kalma (1896-1953) was an important figure from the 1910s until just after the Second World War. He reinvigorated the Frisian Movement and founded the Jongfryske Mienskip (Society for Young Frisians) in 1915. Kalma had a huge impact on the Frisian Movement because of his visionary appeal. Unfortunately, convinced that the Germans would help realise the political goals of the Frisian Movement, he collaborated with the Nazis during the Second World War. This discredited him after 1945 .

Kalma also wrote a series of plays devoted to the Frisian kings from the early Middle Ages (Hoekstra, 2016). The earliest of these was Kening Aldgillis (King Aldgisl, 1920), followed by Kening Finn (King Finn, 1937) and Leafwyn (Lebuinus, 1941). After he had served his prison sentence and his writing ban because of his collaboration during the war, Kalma synthesised these plays in one volume: Keningen fan Fryslân. Fiif toanielstikken yn fersen (Kings of Frisia. Five Plays in Verse, 1949-1951). Of course, Redbad as well as the other Frisian kings are portrayed as heroic champions of paganism and the anti-Frankish, Frisian cause. References "King Aldgisl (1920)", "King Finn (1937)" and "Lebuinus (1981)" was cited in the text but not provided in the

By the end of the twentieth century, Redbad had acquired an indelible position in Frisian culture as the greatest king of the Frisians. In 1968 and 1969, however, Miedema (1968) and Halbertsma (1970, p. 78) pointed out that, although 1969 saw the 1,25oth anniversary of Redbad's death (719), there were no plans for any festivities to commemorate this. Willibrord and Boniface however, had both received ample attention in 1939 and 1954 (and would again in 1989 and 2004) to commemorate the 1,200th anniversary of their deaths.

The character of Redbad continues to play a role in Frisian history in the twenty-first century. In 2004, he was designated de ferneamdste Fries aller tiden 'the most important Frisian of all times' in an internet poll (Leeuwarder Courant, 
11 December 2004). On the internet, his name can be found as the most distant ancestor of several online genealogies. In 1895, the German historian Hugo Jaekel proposed that the counts of Holland descended from Redbad. This theory was revived in the 1990s and has proved to be very tenacious (Nieuwenhuijsen, 2009).

In 2009, Redbad featured in one of the forty-one "windows" or core narratives of the official "canon" of Frisian history written at the request of the province of Friesland..$^{8}$ In 2011, the Frisian writer Willem Schoorstra wrote Rêdbâd. Kronyk fan in kening (Redbad: Chronicle of a King). This historical novel, written with sympathy for the Frisian pagan cause, completes the image of Redbad as an Arthur-like pagan king. Schoorstra chose the historically correct form Rêdbâd, which Miedema (1968) had pointed to. In 2015, an official website for digitalised cultural heritage was launched called www.redbot.frl as an explicit allusion to the king. Finally, 2018 saw both the premiere of a Dutch spectacle movie Redbad. De Legende (Redbad: The Legend), and of an outdoor theatre play (iepenloftspul) in Frisian based on Schoorstra's novel, which simultaneously came out in a reprint and in a Dutch version.

It is safe to conclude with a quotation from Miedema's article on Redbad's name: "Thus the name of the Frisian king and especially its Frisian form has become a symbol of Frisian national sentiments" (Miedema, 1968, p. 54). Redbad is here to stay. He truly has become the "once and future king" of the Frisians.

\section{References}

Acker Strating, G. (1870). Het Ommelander Wapen. Bijdragen tot de Geschiedenis en Oudheidkunde inzonderheid de Provincie Groningen 7, 200-216.

Adam-Even, P. (1954). Cris d'armes des rois chrétiens. Archivum Heraldicum 68, 35-38. Aebischer, P. (1957). Raimbaud et Hamon: Une source perdue de la Chanson de Roland. Le Moyen Age 63, 27-54.

Amersfoordt, H., et al. (eds.; 1849). Jancko Douwama's geschriften. Leeuwarden: Het Provinciaal Friesch Genootschap.

Arends, A. (2002). Inventaris collectie De Goede (unpublished inventory).

Beckmann, G.A. (2005). Pierrepont at a Crossroads of Literatures: An Instructive Parallel between the First Branch of the Karlamagnús Saga, the Dutch Renout and the Dutch Flovent. Neophilologus 89, 587-603.

8 See: https://web-beta.archive.org/web/*/http://www.11en3o.nu/de-kanon-finsters/red bad-en-bonifatius (last consulted: 16 October 2018). 
Beckmann, G.A. (2008). Schwierigkeiten und Triumph einer Überhöhung. Zur Erzählkunst im Rolandslied. Romanistisches Jahrbuch 59, 128-156.

Beckmann, G.A. (2010). Gualter del Hum - Gaiferos - Waltharius (Beihefte zur Zeitschrift für romanische Philologie). Berlin: Walter de Gruyter.

Bénac, J.M. (1916-1923). Les Saints du calendre diocésain d'Auch. Auch: Imprimerie Cocharaux.

Bolhuis van Zeeburgh, J. (1873). Kritiek der Friesche geschiedschrijving. The Hague: Martinus Nijhoff.

Bote, H. (1868). Das Schichtbuch [1514]. In Die Chroniken der niedersächsischen Städte vom 14. bis ins 16. Jahrhunder: Braunschweig (volume 2, pp. 259-493). Leipzig: Verlag von S. Hirzel.

Brault, G.J. (1993). A French Source of the Lord Marshal's Roll (1295-6). The Antiquaries Journal $73,27-36$.

Bremmer, R.H. Jr (1984). Friesland and Its Inhabitants in Middle English Literature. In N.R. Århammar, et al. (eds.), Miscellanea Frisica. In nije bondel Fryske stúdzjes (pp. 357-370). Assen: Van Gorcum.

Bremmer, R.H. Jr (1992). Willibrord through Anglo-Saxon and Frisian Eyes: From History to Myth. In Faltings, V.F., et al. (eds.), Friesische Studien I (NOWELE. Supplement volume 8, pp. 1-28). Odense: Odense University Press.

Bremmer, R.H. Jr (2004). Hir is eskriven. Lezen en schrijven in de Friese landen rond 1300. Hilversum: Verloren.

Breuker, P.H. (ed., 1993). Bruorren Halbertsma. Rimen en teltsjes. Drachten: A.J. Osinga Uitgeverij.

Brook, G.L., and R.F. Leslie (eds., 1967-1978). Layamon: Brut. Volume 2: Text. London: British Museum.

Bruch, H. (1952). Kroniek der Friese Kronieken. Antikritiek op Bolhuis' Kritiek. Leeuwarden: Fryske Akademy.

Bruch, H., et al. (1956). De Fryske flagge. Rapport en advys. It Beaken 18, 33-86.

Buma, W.J., and W. Ebel (eds., 1963). Das Rüstringer recht (= Altfriesische Rechtsquellen 1). Göttingen: Musterschmidt.

Diekamp, W. (ed., 1881). Die Vitae Sancti Liudgeri. Münster: Druck und Verlag der Theissing'schen Buchhandlung.

Dijkstra, W. (1895-1896). Uit Friesland's volksleven van vroeger en later (two volumes). Leeuwarden: M.A. van Seijen.

Dillmann, F.X. (2007). Valhöll. In H. Beck, et al. (eds.), Reallexikon der Germanischen Altertumskunde 35 (pp. 341-366). Berlin: Walter de Gruyter.

van Egmond, W.S. (2005). Radbod van de Friezen, een aristocraat in de periferie. Millennium. Tijdschrift voor Middeleeuwse studies 19, 24-44.

Eis, G. (1936). Drei deutsche Gedichte des 8. Jahrhunderts, aus Legenden erschlossen (= Germanische Studien 181). Berlin: Ebering. 
Faber, R.A. (2003). Verbi Frisici magister Lucius Columba Murray Bakker, master fan it Fryske wurd (three volumes). Leeuwarden: Fryske Akademy.

Feith, J.A., and H. Brugmans (eds., 1911-1912). De kroniek van Abel Eppens tho Equart. Amsterdam:J. Müller.

Gerbenzon, P. (1965). Kleine Oudfriese kronieken, uitgegeven door de werkgroep voor Oudfries aan de Rijksuniversiteit te Utrecht (= Teksten en documenten 4). Groningen: J.B. Wolters.

de Goede, A. (2018 [1946]). Redbad, Koning van Friesland. Utrecht: Zomer \& Keuning. Goodall, J.A. (1990). Rolls of Arms of Kings: Some Recent Discoveries in the British Library. The Antiquaries Journal 70, 82-94.

Goodall, J.A., and G.J. Brault (1994). Some Observations on "A French Source of the Lord Marshal's Roll (1295-6)". The Antiquaries Journal 74, 293-301.

Gosses, G. (1948). In liet fan Redbad en Wodan? It Beaken 10, 78-84.

Halbertsma, H. (1970). Friesische Königssagen. Philologia Frisica annno 1969, 76-90.

Halbertsma, H. (2000). Frieslands Oudheid. Het rijk van de Friese koningen, opkomst en ondergang. Utrecht: Matrijs.

Henstra, D.J. (2012). Friese graafschappen tussen Zwin en Wezer. Een overzicht van de grafelijkheid in middeleeuws Frisia (ca. 700-1200). Assen: Van Gorcum.

Hoekstra, E. (2016). Douwe Kalma. In Schroor, M. (ed.), Nieuwe Encyclopedie van Fryslân (pp. 1420-1421). Gorredijk: Bornmeer.

Hoekstra, J. (1948). Vier Friese kronieken. Rede uitgesproken bij de aanvaarding van het ambt van bijzonder hoogleraar in de Friese taal en letterkunde aan de Universiteit van Amsterdam op 18 October 1948. The Hague: Nijhoff.

IJssennagger, N.L. (2013). Between Frankish and Viking: Frisia and Frisians in the Viking Age. Viking and Medieval Scandinavia 9, 69-98.

Jensma, G.T. (2004). De Gemaskerde God. François HaverSchmidt en het Oera Lindaboek. Zutphen: Walburg Pers.

Jensma, G.T. (2012). Twee eeuwen met, twee eeuwen zonder. De Franeker universiteit voor en na 1811. De Vrije Fries 91, 113-124.

de Jong, A.P. (2009). Knooppunt Halbertsma. Joast Hiddes Halbertsma (1789-1869) en andere Europese geleerden over het Fries en andere talen, over wetenschap en over de samenleving. Hilversum: Verloren.

Jongkees, A.G. (1946). Het Koninkrijk Friesland in de vijftiende eeuw. Groningen: Wolters. Jongkees, A.G. (1961). Gondebald, koning van Friesland. Tijdschrift voor Geschiedenis 74, 309-329.

Koopmans, J. (1993). Van Friese reuzen tot de "kerstentale" van Panurge: Nederland en Nederlanders in Franse middeleeuwse letterkunde. De Gids 156, 146-151.

Langbroek, E., and F. Brands (2015). So viel geschrieben, so wenig geblieben. Eine neue Entdeckung: unbekannte altfriesische Psalmglossen. Amsterdamer Beiträge zur älteren Germanistik 74, 135-146.

- Reference "Langbroek and Brands (2015)" was provided in the reference list but not cited in the text. Please check. 
Langen, G.J. de, and Mol, J.A. (2017). Church Foundation and Parish Formation in Frisia in the Tenth and Eleventh Centuries: A Planned Development? The Medieval Low Countries $4,1-55$.

Lebecq, S. (2007). Paganisme et rites sacrificiels chez les Frisons des VIIe-VIIIe siècles. In Felten, F.J., et al. (eds.), Bonifatius - Leben und Nachwirken. Die Gestaltung des christlichen Europa im Frühmittelalter (pp. 111-120). Mainz: Gesellschaft für mittelrheinische Kirchengeschichte.

- Please provide complete details for reference.

Leeuwarder Courant, 11 December 2004: Redbad overtuigend de beroemdste Fries.

Levison, W. (ed., 1910). Vita Wulframni, in: Monumenta Germaniae Historica Scriptores rerum Merovingicarum (volume 5, pp. 657-673). Hannover: Impensis Bibliopolii Hahniani.

Lübbing, H. (1928). Friesische Sagen von Texel bis Sylt. Jena: H. Lübbing.

Lynch, J.H. (1998). Christianizing Kinship: Ritual Sponsorship in Anglo-Saxon England. Ithaca, NY: Cornell University Press.

Magnus, O. (1555). Historia de gentibus septentrionalibus. Rome.

McConnell, W., et al. (eds., 2002). The Nibelungen Tradition: An Encyclopedia. New York: Routledge.

Meeder, S., and E. Goosmann (2018). Redbad. Koning in de marge van de geschiedenis. Houten: Spectrum.

Meens, R. (2015). With One Foot in the Font: The Failed Baptism of the Frisian King Radbod and the 8th-Century Discussion about the Fate of Unbaptized Forefathers. In Moran, P., and Warntjes, I. (eds.), Early Medieval Ireland and Europe: Chronology, Contacts, Scholarship. A Festschrift for Dáibhí Ó Cróinín (pp. 577-596). Turnhout: Brepols.

Meibom, H. (1688). Rerum Germanicarum, tomi III. Volume 2: Scriptores Germanicos. Helmstedt: Georg Wolfgang Hamm.

Meijering, H.D. (1970). Widekin, thi forma asega. In T. Hoekema, et al. (eds.), Flecht op 'e koai: stúdzjes oanbean oan prof. dr. Wybren Jan Buma ta syn sechstichste jierdei (pp. 53-61). Groningen: Wolters-Noordhoff.

Miedema, H.T.J. (1968). De tweetalige naam van de Friese koning Rêdbâd - Râdbôd aan het begin der Friese en Nederlandse taalgeschiedenis. Mededelingen van de Vereniging van Naamkunde te Leuven en de Commissie voor Naamkunde te Amsterdam, $38-54$.

Millet, V. (1999). Sansueña, oder: Wie aus dem Land der Sachsen die Stadt Zaragoza wurde. Anmerkungen zu Don Quijote II,26. Germanisch-romanische Monatsschrift 49, 19-34.

Moisan, A. (1986). Répertoire des noms propres de personnes et de lieux cités dans les chansons de geste (Part 2, volume 4). Geneva: Droz.

Mol, J.A., and J. Smithuis (2008). De Friezen als uitverkoren volk. Religieus-patriottische geschiedschrijving in vijftiende-eeuws Friesland.Jaarboekvoor Middeleeuwse Geschiedenis 11, 165-204. 
Nicolay, J.A.W. (2014). The Splendour of Power. Early Medieval Kingship and the Use of Gold and Silver in the Southern North Sea Area (5th to 7th century AD) (= Groningen Archaeological Studies 28). Groningen: Barkhuis.

Nieuwenhuijsen, K. (2009). De afstamming van de Hollandse graven. De Nederlandsche Leeuw 126(2), 29-39.

Nijdam, J.A. (2008). Lichaam, eer en recht in middeleeuws Friesland. Een studie naar de Oudfriese boeteregisters. Hilversum: Verloren.

Nijdam, J.A. (2009). Klinkende munten en klinkende botsplinters in de Oudfriese rechtsteksten: continuïteit, discontinuïteit, intertekstualiteit. De Vrije Fries 89, $45^{-66 .}$

Noomen, P.N. (1994). Suffridus Petrus en de Friese identeit. It Beaken 56(2/3), 146-187.

Noomen, P.N. (2009). De stinzen in middeleeuws Friesland en hun bewoners. Hilversum: Verloren.

Ottema, J.G. (ed., 1847). Worperi Tyaerda ex Rensimageest, prioris in Thabor, Chronicorum Frisiae libri tres. Leeuwarden: unknown.

Pastoureau, M. (2001). Blue: The History of a Color. Princeton, NJ: Princeton University Press.

Pesch, A. (2003). Orakel. In H. Beck, et al. (eds.), Reallexikon der Germanischen Altertumskunde 22 (pp. 134-139). Berlin: Walter de Gruyter.

Pirot, F. (1972). Recherches sur les connaissances littéraires des troubadours occitans et catalans des XIIe et XIIIe siècles. Barcelona: Real Academia de Buenas Letras.

Pita, P.F. (ed., 1882). Le codex de Saint-Jacques-de-Compostelle (Liber de miraculis $S$. Jacobi), livre IV. Paris: Maisonneuve.

de Ricquer, M. (1987). La heráldica en el Libro del Conoscimiento y el problema de su datación. Dicenda. Cuadernos de Filología Hispánica 6, 313-319.

Salomon, A. (2000). Friesische Geschichtsbilder. Historische Ereignisse und kollektives Gedächtnis im Mittelalterlichen Friesland. Aurich: Ostfriesische Landschaftliche Verlags- und Vertriebsgesellschaft.

Samplonius, K. (1993). Rex non reditvrvs. Notes on Theoderic and the Rök-Stone. Amsterdamer Beiträge zur älteren Germanistik 37, 21-31.

Sargent, B.N. (ed., 1967). Le livre du roy Rambaux de Frise. Chapel Hill, NC: University of North Carolina at Chapel Hill Department of Romance Studies.

Schmidt, H. (1963). Studien zur Geschichte der friesischen Freiheit. Jahrbuch der Gesellschaft für bildende Kunst und vaterländische Altertümer zu Emden 43, 5-78.

Sello, G. (1921-1922). Radbod-Erinnerungen. Upstalsboom-Blätter 10, 1-16.

Sundermann, F. (1922). Der Upstalsboom. Ostfrieslands Volksüberlieferungen. Aurich: Dunkmann.

Tveitane, M. (1995). Forseti. In H. Beck, et al. (eds.), Reallexikon der Germanischen Altertumskunde 9 (pp. 343-345). Berlin: Walter de Gruyter.

Verbij-Schillings, J. (1997). Het beeld van de Friezen in de Hollandse geschiedschrijving van de vijftiende eeuw. In Breuker, P.H., and Janse, A. (eds.), Negen eeuwen Friesland- 
Holland. Geschiedenis van een haat - liefdeverhouding (pp. 109-119). Leeuwarden: Fryske Akademy.

Voorwinden, N. (2003). Er was ze Friesen herre: zum verhältnis zwischen Friesen und Dänen in der "Kudrun”. In Zatloukal, K. (ed.), Mittelhochdeutsche Heldendichtung ausserhalb des Nibelungen- und Dietrichkreises (Kudrun, Ortnit, Waltharius, Wolfdietriche) (pp. 213-229). Vienna: Fassbaender.

de Vries, H. (1995). Wapens van de Nederlanden. De historische ontwikkeling van de heraldische symbolen van Nederland, België, hun provincies en Luxemburg. Amsterdam: Schilt Publishing.

Vries, O. (2015). Frisonica libertas: Frisian Freedom as an Instance of Medieval Liberty. Journal of Medieval History 41, 229-248.

Waterbolk, E.H. (1995). Een vervalser betrapt? Een probleem in de Friese geschiedschrijving. In Bergsma, W., et al. (eds.), E.H. Waterbolk. Omtrekkende bewegingen (pp. 88-104). Hilversum: Verloren.

Wiersma, J.P. (1934). Friesche sagen. Leeuwarden: Van Seijen.

Wiersma, J.P. (1937). Friesche mythen en sagen. Leeuwarden: Van Seijen.

Wiersma, J.P. (1973). Friese volkssprookjes. Leeuwarden: Van Seijen.

Wild, B., and J. Altheer (eds., 1802). Joachimi Hopperi, Frisii - Epistolae ad Viglium ab Aytta Zuichemum sanctioris consilii praesidem. Utrecht: unknown. 